\title{
KARAKTERISTIK PENERAPAN HUKUM EKONOMI DALAM PEMBANGUNAN DI INDONESIA
}

\author{
Hartanto \\ Fakultas Hukum Universitas Widya Mataram \\ nDalem Mangkubumen KT III/ 237, Kraton, Yogyakarta \\ E-mail: hartanto.yogyakarta@gmail.com
}

\begin{abstract}
Economic law develops as the background of the rapid growth and development of economic activity in almost all parts of the world. The presence of the main economic law aims to regulate and limit all economic activities for the implementation of economic activity and economic development are not always appropriate and ignore the rights and interests of the wider community. Law of increasing economic development, one example when entering the era of the free market. Objective application of the law in the Indonesian economy is to set the rule of law to be easy in terms of planning related to the economy and pemerataannya for economic policy towards a pro-people. Therefore, it is necessary that every topic of discussion was the economy or technology experts and legal experts are concerned, especially regarding the development of various forms of corporate law in the Indonesian economy to come, which, according to the Working Group for the Economy, Finance and Industry (Ekuin) seen as a problem that is still not enough to be touched by the Indonesian Corporate Law. Economics that must be addressed in the conceptual, systemic and professional, but also the field of economic law and must be studied in line with the policy direction of the economy.
\end{abstract}

Keywords: contract, economic development, government, law of economics, social economy.

\begin{abstract}
Abstrak
Perkembangan hukum ekonomi dilatarbelakangi oleh pesatnya pertumbuhan dan perkembangan aktivitas ekonomi di seluruh belahan dunia. Kehadiran hukum ekonomi tersebut utamanya bertujuan untuk mengatur dan membatasi segala aktivitas perekonomian agar pelaksanaan kegiatan perekonomian dan pembangunan ekonomi senantiasan sesuai dan tidak mengabaikan hak dan kepentingan masyarakat luas.. Tujuan penerapan hukum ekonomi di Indonesia adalah untuk mengatur peraturan hukum agar mudah dalam perencanaan yang berkaitan dengan hal perekonomian dan pemerataannya untuk menuju pengambilan kebijakan ekonomi yang pro rakyat.Dalam hukum ekonomi Indonesia yang akan datang, yang menurut Kelompok Kerja Bidang Ekuin dilihat sebagai masalah yang masih belum cukup disentuh oleh Hukum Korporasi Indonesia. bidang ekonomi yang harus ditangani secara konseptual, sistemik dan profesional, tetapi bidang hukum ekonomi harus sejalan dan searah dengan kebijaksanaan serta pengambilan keputusan di bidang ekonomi.
\end{abstract}

Kata kunci: Hukum Ekonomi, Pemerintah, Perkembangan. 


\section{PENDAHULUAN}

Saat ini, istilah hukum ekonomi sudah bukan lagi merupakan sesuatu yang asing, bahkan hukum ekonomi merupakan hukum yang cukup dikenal dan sangat populer. Keberadaan bidang hukum ekonomi dalam sistem hukum Indonesia sudah tidak diragukan lagi ${ }^{1}$. Berbeda dengan pada awal dikenalnya hukum di Indonesia yang sempat menimbulkan kontroversi sebagai bagian dari sistem hukum. Keberadaan hukum ekonomi di Indonesia merupakan bagian terpenting yang tidak dapat di pisahkan saat ini. Berdasarkan penjelasan Pasal 1 Ayat (3) Undang-Undang Dasar Negara Republik Indonesia tahun 1945 yang menguraikan mengenai konsep negara hukum di indonesia. Sebagai negara hukum, Indonesia menerima hukum sebagai ideologi untuk menciptakan ketertiban, keamanan, keadilan serta kesejahteraan bagi warga negaranya, untuk itu UUD Negara Republik Indonesia 1945 sebagai dasar kostitusi menjamin keberadaan bidang hukum ekonomi, hal ini dapat dilihat dalam Pasal 33 UUD Negara Republik Indonesia 1945 sebagai berikut : Ayat (1) berbunyi; Perekonomian disusun sebagai usaha bersama berdasar atas azas kekeluargaan, Ayat (2); Cabang-cabang produksi yang penting bagi negara dan yang menguasai hajat hidup orang banyak dikuasai oleh Negara, Ayat (3) menyebutkan; Bumi, air dan kekayaan alam yang terkandung didalamnya dikuasai oleh negara dan dipergunakan untuk sebesar-besarnya kemakmuran rakyat, Ayat (4), Perekonomian nasional diselenggarakan berdasar atas demokrasi ekonomi dengan prinsip kebersamaan, efisiensi berkeadilan, berkelanjutan, berwawasan lingkungan, kemandirian, serta dengan menjaga keseimbangan kemajuan dan kesatuan ekonomi nasional.

Konsep hukum ekonomi merupakan suatu pengaturan-pengaturan hukum dalam bidang ekonomi dan bukan hukum dalam makna determinasi ekonomi yang timbul dalam aktivitas perekonomian (ilmu ekonomi). Kedua hal tersebut hampir sama maknanya ketika kita pertama kali mendengar istilah hukum ekonomi. Hukum ekonomi berkembang dilatarbelakangi semakin pesatnya pertumbuhan dan perkembangan aktivitas ekonomi hampir di seluruh belahan dunia. Kehadiran hukum ekonomi tersebut utamanya bertujuan untuk mengatur dan membatasi segala aktivitas perekonomian agar pelaksanaan kegiatan perekonomian dan pembangunan ekonomi senantiasa sesuai dan tidak mengabaikan hak dan kepentingan masyarakat luas ${ }^{2}$. Menurut Jeremy Bentham, hak adalah anak dari hukum. Dari hukum yang nyata timbul hak yang nyata. Sebaliknya dari hukum yang imajiner yaitu hukum alam, timbul hak yang bersifat imajiner. Hakhak alamiah benar-benar tidak masuk akal. Sebelum Bentham, David Hume juga berpendapat bahwa hukum alam dan hak-hak alamiah bersifat metafisis dan tidak nyata. Oleh karena itu Bentham berpendapat bahwa hukum yang nyata bukanlah hukum alam, melainkan hukum yang dibuat oleh lembaga legislatif ${ }^{3}$. Dalam teori kemanfaatan yang pertama kali dijumpai dalam karya Bentham yang kemudian diadopsi oleh Rudolf von Campbell, dan lain-lain. Menurut Ihering, tujuan hukum bukanlah melindungi kehendak individu, melainkan melindungi kepenttingankepentingan tertentu. Oleh karena itu ia mendefinisikan hak sebagai kepentingan-kepentingan yang dilindungi oleh hukum. Kepentingan-kepentingan itu bukan diciptakan oleh negara karena kepentingan itu telah ada dalam kehidupan bermasyarakat dan negara hanya memilihnya

\footnotetext{
${ }^{1}$ Adi Sulistiyono, Reformasi Hukum Ekonomi dalam Era Globalisasi Ekonomi, Surakarta. UNS Press, 2005, hlm 2.

${ }^{2}$ Gunarto Suhardi, Peranan Hukum Dalam Pembangunan Ekonomi, Yogyakarta, Universitas Atma Jaya, 2002, $\mathrm{h} \operatorname{lm} 7$.

${ }^{3}$ Peter Mahmud Marzuki, Pengantar Ilmu Hukum, Jakarta, Kencana, 2016, hlm. 142.
} 
mana yang harus dilindungi ${ }^{4}$. Paton berpendapat bahwa esensi hak bukanlah kekuasaan yang dijamin oleh hukum, melainkan kekuasaan yang dijamin oleh hukum untuk merealisasi suatu kepentingan. Untuk menopang pendapat tersebut, Paton mengemukakan bahwa kehendak manusia tidak bekerja tanpa maksud apa-apa tetapi mengingatkan tujuan-tujuan tertentu, yaitu kepentingan. Oleh karena itu, ia menegaskan bahwa kepentingan-kepentingan adalah objek keinginan manusia. ${ }^{5}$

Kehadiran hukum ekonomi sebagai bagian dari esensi hal yg merpakan jaminan atau amanah dari konstitusi. Menurut Jimly Asshiddiqie, Hak konstitusional merupakan hak-hak yang dijamin dalam dan oleh Undang-Undang Dasar Negara Republik Indonesia 1945. Penjaminan hak tersebut baik dinyatakan secara tegas maupun secara tersirat ${ }^{6}$. Untuk itu perlunya konstruksi hukum ekonomi dalam menjamin kepentingan manusia yang berdasrkan pada konsep suatu keadilan, Menurut Theo Huijbers, hukum harus terjalin erat dengan keadilan, Undang-undang hanya dapat menjadi hukum bila memenuhi prinsip-prinsip keadilan. Adil merupakan unsur konstitusif segala pengertian tentang hukum ${ }^{7}$.

\section{TELAAH KONSEP}

Konsep hukum ekonomi pembangunan merupakan pengaturan mengenai hukum yang meliputi pengaturan dan pemikiran hukum mengenai cara peningkatan dan pengembangan kehidupan perekonomian di Indonesia secara nasional atau menyeluruh, sedangkan dengan konsep hukum ekonomi sosial adalah pengaturan tentang bagaimana hasil pembangunan ekonomi nasional dapat dibagi dengan adil dan merata sesuai nilai-nilai kemanusiaan. Diharapkan kedua konsep hukum ekonomi pembangunan maupun hukum sosial pembangunan ini, keduaduanya dapat berkembang seiring dan mencapai tujuan secara proporsioanal dan berimbang. Sehingga pengaturan maupun pembagian usaha-usaha pembangunan ekonomi dalam arti peningkatan kehidupan ekonomi nasional secara keseluruhan; dan merata, pendeknya terjadi perkembangan seiring antara pembangunan dan pemerataan hasil pembangunan.

\section{METODE PENELITIAN}

Jenis penelitian ini adalah penelitian hukum normatif, yaitu penelitian yang menggunakan hukum sebagai landasan norma, maka penelitian ini didasarkan pada penelitian perpustakaan yang berfokus pada membaca dan menganalisis bahan primer dan sekunder berupa buku-buku terkait hukum ekonomi di Indonesia, yaitu hukum ekonomi pembangunan dan hukum ekonomi sosial dengan tujuan untuk mengetahui hal mendasar bagi keberadaan suatu norma hukum. Dalam penelitian hukum normatif, peneliti menggunakan beberapa pendekatan, yaitu pendekatan Undang-Undang Dasar 1945 dan pendekatan undang-undang karena dalam pendekatan ini, peneliti mempelajari berbagai aturan hukum dan tema sentralnya.

\footnotetext{
${ }^{4}$ G.W Paton, Textbook of of Jurisprudence, English language book Society, Oxford University Press, London, 1972. dikutip dari Peter Mahmud Marzuki I, Ibid., hlm. 151.

${ }^{5}$ Ibid., hlm. 290.

${ }^{6}$ Jimly Asshiddiqie, Konstitusi E Konstitusionalisme Indonesia, Jakarta, Edisi Revisi, Konstitusi Press, 2005, hlm. 343

${ }^{7}$ Theo Huijbers, Filsafat Hukum Dalam Lintas Sejarah, Yogyakarta, Kanisius, 1990, hlm.70.
} 


\section{PEMBAHASAN}

\section{Model penerapan Hukum Ekonomi di Indonesia}

Dalam teori hukum, istilah "Hukum Ekonomi" merupakan terjemahan dari Economisch Recht (Belanda) atau Economic Law (Amerika) ${ }^{8}$. Namun demikian, pengertian atau konotasi Economisch Recht di Belanda ternyata berbeda dengan arti Economic Law di Amerika Serikat. Definisi Economisch Recht (Belanda) sebenarnya berasal dari istilah Droit É'conomique (Perancis) dan setelah perang dunia kedua berkembang menjadi Droit de l'Économie yang berarti kaidahkaidah hukum administrasi negara (terutama yang berasal dari kekuasaan eksekutif yang mulai sekitar tahun 1930-an diadakan untuk membatasi kebebasan pasar di Perancis, demi keadilan ekonomi bagi rakyat miskin, agar tidak hanya mereka yang berduit saja yang dapat memenuhi kebutuhan pangan, tetapi agar rakyat petani dan buruh juga tidak akan mati kelaparan. Krisis ekonomi dunia yang dikenal dengan nama "malaise" di tahun 1930-an itulah yang mengakibatkan adanya koreksi terhadap paham pasar bebas, karena pemerintah Perancis merasa wajib untuk mengeluarkan peraturan Hukum Administrasi Negara yang menentukan harga maksimum dan minimum bagi bahan-bahan pokok dan menentukan izin pemerintah yang diperlukan untuk berbagai usaha di bidang ekonomi, seperti untuk membuka perusahaan, menentukan banyaknya penanaman modal, bidang usaha tempat investasi modal, mengimpor atau mengekspor barang, tujuan, kuantitas, kualitas, dan sebagainya

Peraturan-peraturan hukum administrasi negara seperti itu dicakup dengan nama Droit Économique (hukum ekonomi dalam arti sempit). Kemudian, setelah perang dunia kedua, yaitu sekitar tahun 1945, negara-negara Eropa yang harus membangun kembali negaranya dengan bantuan International Bank for Reconstruction, PBB diwajibkan menyusun Rencana Pembangunan Lima Tahun kala itu, yang mendasari keputusan International Bank for Reconstruction untuk memberi bantuan kepada negara yang bersangkutan. Persetujuan internasional antara IBR dan negara penerima bantuan dituangkan dalam kebijaksanaan dan peraturan hukum negara penerima bantuan untuk dilaksanakan, seperti misalnya sampai kini juga terjadi di Indonesia sejak orde baru. Seluruh kebijaksanaan dan peraturan hukum yang tidak terbatas pada Hukum Administrasi Negara saja, tapi juga mengatur hal-hal yang termasuk substansi Hukum Pidana, Hukum Perdata, Hukum Dagang, Hukum Perdata Internasional, bahkan Hukum Acara Perdata dan Pidana, dicakup dengan nama Droit de l'Économique atau hukum ekonomi dalam arti luas9.

Hukum ekonomi merupakan keseluruhan norma-norma yang dibuat oleh pemerintah atau penguasa sebagai satu personifikasi dari masyarakat yang mengatur kehidupan ekonomi di mana kepentingan individu dan kepentingan masyarakat saling berhadapan. Dalam normanorma ini, pemerintah mencoba memasukkan ketentuan-ketentuan yang lebih ditekankan kepada kepentingan masyarakat, bahkan apabila perlu membatasi kepentingan dan hak-hak individu. Hukum ekonomi merupakan suatu hubungan sebab akibat atau pertalian peristiwa ekonomi yang saling berhubungan satu dengan yang lain dalam kehidupan ekonomi sehari-hari dalam masyarakat atau lahirnya hukum ekonomi dikarenakan meningkatnya pertumbuhan dan perkembangan perekonomian masyarakat.

${ }^{8}$ T Mulya Lubis, Hukum dan Ekonomi : Beberapa Pilihan Masalah, Jakarta, Pustaka Sinar Harapan, 1991, hlm 2.

${ }^{9}$ Hikmahanto Juwana, Bunga Rampai Hukum Ekonomi dan Hukum Internasional, Jakarta, Lentera Hati, 2002, hlm 3 
Menurut beberapa ahli, terdapat beberapa pengertian tentang hukum ekonomi, antara lain: a. Rochmat Soemitro berpendapat bahwa hukum ekonomi adalah keseluruhan norma atau kaidah hukum yang dibuat oleh pemerintah atau otoritas penguasa sebagai sebuah personifikasi dari masyarakat yang mengatur kehidupan ekonomi, dimana kepentingan individu dan kepentingan masyarakat saling berhadapan satu sama lain.

b. Adi Sulistiyono berpendapat bahwa hukum ekonomi adalah peraturan perundang-undangan yang dibuat oleh lembaga atau pejabat yang memliki legalitas (kewenangan) untuk mengatur aktifitas dan perilaku juga pertumbuhan sektor ekonomi serta penyelesaian sengketa yang terjadi dimana substansi peraturan perundang-undangan tersebut dipengaruhi oleh sistem ekonomi dalam konstitusi negara yang bersangkutan.

c. Sunaryati Hartono berpendapat bahwa hukum ekonomi adalah keseluruhan kaidah dan putusan hukum yang secara khusus mengatur kegiatan perekonomian di Indonesia. Lebih lanjut lagi Sunaryati Hartono berpendapat bahwa hukum ekonomi merupakan penjabaran atas hukum ekonomi pembangunan dan hukum ekonomi sosial ${ }^{10}$.

Ada dua model hukum ekonomi di Indonesia, hukum ekonomi pembangunan dan hukum ekonomi sosial. Hukum ekonomi pembangunan merupakan pengaturan mengenai hukum yang meliputi pengaturan dan pemikiran hukum mengenai cara peningkatan dan pengembangan kehidupan perekonomian di Indonesia secara nasional atau menyeluruh, sedangkan dengan hukum ekonomi sosial adalah pengaturan tentang bagaimana hasil pembangunan ekonomi nasional dapat dibagi dengan adil dan merata sesuai nilai-nilai kemanusiaan ${ }^{11}$. Ada berbagai studi kasus-kasus hukum ekonomi antara lain sebagai berikut: jika harga sembako naik maka harga barang lain biasanya ikut merambat naik; bila di suatu lokasi berdiri sebuah pusat pertokoan hipermarket besar dengan harga yang sangat murah maka dapat dipastikan peritel atau toko-toko kecil yang berada di sekitarnya akan kehilangan omset atau mati gulung tikar; jika nilai kurs Dollar Amerika naik tajam maka banyak perusahaan yang modalnya berasal dari pinjaman luar negeri akan bangkrut; turunnya harga elpiji akan menaikkan jumlah penjualan kompor gas baik buatan dalam negeri maupun luar negeri; semakin tinggi bunga bank tabungan maka jumlah uang beredar akan turun dan terjadi penurunan jumlah permintaan barang dan jasa secara umum; dan lain-lain ${ }^{12}$.

Sementara itu, hukum ekonomi di Indonesia memiliki asas-asas: manfaat; keadilan dan pemerataan yang berperikemanusiaan; keseimbangan, keserasian dan keselarasan dalam perikehidupan; kemandirian yang berwawasan kebangsaan; usaha bersama atau kekeluargaan; demokrasi ekonomi; dan membangun tanpa merusak lingkungan. Hukum ekonomi merupakan penjabaran hukum ekonomi pembangunan dan hukum ekonomi sosial, sehingga hukum ekonomi memiliki dua aspek, ${ }^{13}$ yaitu:

a. Aspek pengaturan usaha-usaha pembangunan ekonomi dalam arti peningkatan kehidupan ekonomi nasional secara keseluruhan; dan

\footnotetext{
${ }^{10}$ Hikmahanto Juwana, Op., Cit,,hlm 5

${ }^{11}$ Christianto Wibisono, , Menelusuri Akar Krisis Indonesia, Jakarta, PT. Gramedia Pustaka Utama, 1998, hlm 18

${ }^{12}$ Ai Siti Farida, Sistem Ekonomi Indonesia, Jakarta, Pustaka Setia, 2011, hlm 24

${ }^{13}$ Hikmahanto Juwana, Op., Cit „,hlm 15
} 
b. Aspek pengaturan usaha-usaha pembagian hasil pembangunan ekonomi secara merata di antara seluruh lapisan masyarakat, sehingga setiap warga negara dapat menikmati hasil pembangunan ekonomi itu sesuai dengan sumbangannya kepada usaha pembangunan ekonomi tersebut.

Hukum ekonomi jika didasarkan pada klasifikasi internasional pembagiannya adalah sebagai berikut ${ }^{14}$ :

a. Hukum ekonomi pertanian atau agraria, yang didalamnya termasuk norma-norma mengenai pertanian, perburuan, peternakan, perikanan dan kehutanan;

b. Hukum ekonomi pertambangan;

c. Hukum ekonomi industri, industri pengolahan;

d. Hukum ekonomi pembangunan;

e. Hukum ekonomi perdagangan, termasuk juga norma-norma mengenai perhotelan dan pariwisata;

f. Hukum ekonomi prasarana termasuk gas, listrik air, jalan;

g. Hukum ekonomi jasa-jasa, profesi dokter, advokat, pembantu rumah tangga, tenaga kerja;

h. Hukum ekonomi angkutan;

i. hukum ekonomi pemerintahan termasuk juga pertahanan dan keamanan (hankam), dan lain-lain.

\section{Prinsip Pembangunan Hukum Ekonomi di Indonesia}

Prinsip hukum secara filosofis merupakan landasan atau pokok dasar berfikir atau bertindak yangmemberikan arah, tujuan serta penilaian fundamental, mengandung nilai-nilai dan etis ${ }^{15}$. Beberapa ahli memberikan batasan atau pengertian prinsip hukum sebagai berikut:

a. Bellefroid mengemukakan bahwa prinsip hukum umum adalah norma dasar yang di jabarkan dari hukum positif dan yang oleh ilmu hukum tidak dianggap berasal dari aturan aturan yang lebih umum. Jadi prinsip hukum umum merupakan kristalisasi (pengendapan) hukum positif dalam suatu masyarakat.

b. Van Eikema Homes mengemukakan bahwa prinsip bukan norma hukum yang konkret, tetapi sebagai dasar dasar umum atau penunjuk penunjuk bagi hukum yang berlaku. Jadi merupakan dasar-dasar petunjuk arah dalam pembentukan hukum positif sehingga dalam pembentukan hukum praktis harus berorientasi pada prinsip prinsip hukum.

c. Paul Scholte, menguraikan bahwa prinsip hukum dalah pikiran pikirkan dasar yang terdapat di dalam dan di belakang sistem hukum masing masing yang di rumuskan dalam aturan-aturan, perundang-undangan dan putusan hakim yang berkenaan dengan ketentuan-ketentuan dan keputusan individu dapat di pandang sebagai penjabarannya

Tegaskan oleh Niewenhuis bahwa prinsip- prinsip hukum berfungsi sebagai pembentuk produk hukum peradilan karena tidak hanya mempengaruhi hukum positif melainkan sistem peradilan yang baik sehingga suatu penegakan hukum yang baik tidak akan ada tanpa adanya prinsip prinsip yang di tuangkan dalam produk hukum ${ }^{16}$. Berdasarkan uraian diatas posisi prinsip

\footnotetext{
${ }^{14}$ Ibid.,hlm 16

${ }^{15}$ M. Noor Syam, Penjabaran Filsafat Pancasila Dalam Filsafat Hukum, Malang, Lab Pancasila Ikip, Hlm 74

${ }^{16}$ Yohanes Sogar Simamora, Hukum Perjanjian Prinsip Hukum Kontrak Pengadaan Barang dan Jasa Oleh Pemerintah, Laksbang
} 
hukum sebagai meta norma hukum pada dasarnya memberikan arah tujuan serta penilaian fundamental bagi keberadaan suatu norma hukum. Dasar atau landasan tersebut di taungkan dalam dasar konstitusi dalam Pasal 33 UUD NRI 1945 yang menyatakan sebagai berikut Ayat (1) berbunyi; Perekonomian disusun sebagai usaha bersama berdasar atas azas kekeluargaan, Ayat (2); Cabang-cabang produksi yang penting bagi Negara dan yang menguasai hajat hidup orang banyak dikuasai oleh Negara, Ayat (3) menyebutkan ; Bumi, air dan kekayaan alam yang terkandung didalamnya dikuasai oleh Negara dan dipergunakan untuk sebesar-besarnya kemakmuran rakyat, Ayat (4), Perekonomian nasional diselenggarakan berdasar atas demokrasi ekonomi dengan prinsip kebersamaan, efisiensi berkeadilan, berkelanjutan, berwawasan lingkungan, kemandirian, serta dengan menjaga keseimbangan kemajuan dan kesatuan ekonomi nasional.

Berdasarkan ketentuan diatas makan Penerapan hukum ekonomi yang ada di Indonesia sebagai bagian dalam membagun suatu keadilan yang mengatur hal hal sebagai berikut:

a. Mengatur peraturan hukum agar mudah dalam perencanaan yang berkaitan dengan hal perekonomian.

b. Mengatur adanya pemerataan pembangunan dan pemerataan distribusi pendapatan jika merujuk kepada hukum pembangunan nasional. Hal ini menyangkut kepada hukum ekonomi sosial yang berisi pemerataan pembangunan agar semua hasil pembangunan bisa dinikmati oleh semua kalangan lapisan masyarakat dimana pun mereka berada dalam wilayah Indonesia.

c. Mengatur kebijakan ekonomi agar tidak terjadi pelanggaran hukum dalam aspek sosial saat diambil sebuah keputusan kebijakan ekonomi.

Inti hukum ekonomi ini adalah semua kebijakan atas dasar kepentingan masyarakat dan negara, sehingga kepentingan negara bisa tercapai tanpa harus menyengsarakan masyarakat. Itulah beberapa hukum ekonomi yang terjadi dan terdapat di negara Indonesia, baik secara yang mudah terlihat atau pun di alami, sehingga ke depannya diharapkan bisa berjalan dengan baik dan berfungsi dengan baik demi kesejahteraan seluruh masyarakat Indonesia ${ }^{17}$.Bentham berpendapat ${ }^{18}$ :

"Nature has placed mankind under the governance of two sovereign masters, pain and pleasure. It is for them alone to point out what we ought to do, as well as to determine what we shall do. On the one hand the standard of right and wrong, on the other the chain of causes and effects, are fastened to their throne. They govern us in all we do, in all we say, in all we think: every effort we can make to throw off our subjection, will serve but to demonstrate and confirm it. In word a man may pretend to abjure their empire: but in reality he will remain. Subject to it all the while. The principle of utility recognizes this subjection, and assumes it for the foundation of that system, the object of which is to rear the fabric of felicity by the hands of reason and of law. Systems which attempt to question it, deal in sounds instead of sense, in caprice instead of reason, in darkness instead of light."

Berdasarkan pernyataan Bentham tersebut alam telah menempatkan umat manusia dibawah kendali dua penguasaan, rasa sakit (pain) dan rasa senang (pleasure). Hanya keduanya yang menunjukkan apa yang seharusnya manusia lakukan, dan menentukan apa yang akan manusia lakukan. Standar benar dan salah di satu sisi, maupun sebab akibat pada sisi lain, melekat erat

Pressindo, Yogyakarta, 2009, hlm 36-37.

${ }^{17}$ Sumantoro, Hukum Ekonomi, Jakarta, UI Press, 2008, hlm 6

${ }^{18}$ Jeremy Bentham, An Introduction to the Principles Of Morals and Legislation, Kitchener, Batoche Books, 2000, hlm 15 
pada dua kekuasaan tersebut. Terkait dengan prinsip utilitas Bentham mendasarkan keseluruhan filsafatnya pada dua prinsip yaitu prinsip asosiasi (associationprinciple) dan prinsip kebahagiaan terbesar (greates happiness principle). Prinsip asosiasi berakar pada psikologi tentang adanya refleks yang dikondisikan. Dalam konteks ini Bentham menunjukkan bahwa hukum memiliki kemampuan sebagai stimulus untuk mengkondisikan ide-ide tentang kebaikan ${ }^{19}$. Sedangkan prinsip kedua yaitu prinsip tentang kebahagiaan terbesar.

Kesenangan atau kemanfaatan sebagaimana dimaksud di atas dapat diraih dengan ukuran akibat (konsekuensi). Dengan demikian hukum yang baik adalah hukum yang bisa memberikan akibat yang paling bermanfaat atau menimbulkan kebahagiaan terbesar untuk jumlah orang terbesar (the greatest happiness of the greatest number). Kebahagiaan tersebut muncul tidak lepas dari fungsi hukum itu sendiri. Menurut Bentham "All the functions of law may be referred to these four heads: to provide subsistence; to produce abudance; to favour equality; and to maintain security." selanjutnya dalam memaknai hukum, menurut Bentham hukum yang merupakan sekumpulan tanda (assemblage of sign $)^{20}$. tanda yang dimaksud oleh bentam adalah ungkapan kehendak (the expression of will) yang muncul dari kehendak yang di pahami dan di serap oleh penguasa negara. lebih lanjut Bentham menyatakan bahwa:

"A law may be defined as an assemblage of sign declarative of a volition conceived or adopted by the sovereign in a state, concerning the conduct to be observed in acertain case by a certain person or class of persons, who in the case in question are or are supposed to be subject to his power: such volition trusting for its accomplishment to the expectation of certain events which it is intended such declaration should upon occasion be a means of bringing to pass, and the prospect of which it is intended should act as a motive upon those whose conduct is in question"21.

\section{Fungsi Hukum Ekonomi Dalam Pembangunan Hukum Di Indonesia}

Ditinjau dari segi fungsinya, pembangunan hukum ekonomi di Indonesia berfungsi sebagai $^{22}$ :

a. Sarana pemeliharaan ketertiban dan kemamanan;

b. Sarana pembangunan;

c. Sarana penegak keadilan, dan

d. Sarana pendidikan masyarakat.

Keempat fungsi tersebut dapat diterapkan dalam hukum ekonomi yang merupakan suatu sistem hukum nasional yang berorientasi kepada kesejahteraan rakyat. Sementara itu, hukum ekonomi bertugas untuk:

a. Membentuk dan menyediakan sarana dan prasarana hukum;

b. Meningkatkan pembangunan ekonomi;

c. Melindungi kepentingan ekonomi warga;

d. Meningkatkan kesejahteraan masyarakat;

e. Menyusun \& menerapkan sanksi bagi pelanggar; dan

f. Membantu terwujudnya tata ekonomi internasional baru melalui sarana \& pranata hukum.

${ }^{19}$ Shindarta, Utilitarianisme, Jakarta, Penerbit UPT Universitas Tarumanegara, 2007, hlm 19

${ }^{20}$ Jeremy Bentham, Op.,Cit.,hlm 96

${ }^{21}$ M.D.A. Freeman, Lloyds Introduction to Jurisprudence, London, Steven And Sons, 2001, Hlm 187-188.

${ }^{22}$ Sumantoro., Op.Cit., hlm 19. 
Melalui analisis yang mendalam dan profesional tentang hukum ekonomi di Indonesia ${ }^{23}$, akhirnya dapat terungkap hal-hal berikut :

a. Kebijaksanaan ekonomi nasional baik secara makro, tetapi juga secara mikro yang seperti apa yang harus diambil, agar ekonomi nasional setelah tahun 2003 menjadi lebih sehat dan sesuai denga Pasal 33 dan 34 UUD (setelah 4 kali amandemen).

b. Kebijaksanaan itu dijabarkan lebih lanjut mengenai bagaimana memberdayakan usaha kecil dan menengah dalam rangka peningkatan peranan swadaya ekonomi dalam Ekonomi Nasional pasca tahun 2003; bagaimana mengembangkan sistem Industri, Transportasi dan Perdagangan Luar Negeri kita tanpa merugikan lingkungan hidup kita bagi generasi-generasi mendatang; bagaimana memperbaiki Sistem Keuangan dan Sistem Perbankan kita agar dapat menunjang segala kegiatan pemerintah maupun pengusaha dan konsumen Indonesia dengan efesien, efektif, seimbang dan merata; bagaimana sebaiknya mengelola sumber daya kelautan, perikanan dan perhubungan laut kita di abad ke-21; bagaimana mencegah KKN dalam birokrasi dengan meningkatkan proses dan prosedur pelayanan publik; dan lain-lain. Kebijaksanaan umum di bidang ekonomi itu perlu diketahui oleh para pembentuk hukum mau pun penegak hukum untuk dapat menyusun Sistem Hukum Ekonomi (dalam arti Droit de l'Économie; maupun Droit É'conomique seperti yang diutarakan di atas). Khususnya, undangundang baru dan institusi baru yang mana yang perlu diadakan, undang-undang lama yang mana yang perlu diperbaiki atau dihapus, pranata dan lembaga hukum mana yang harus diadakan atau diubah/dimodifikasi atau ditiadakan, dan Iain-lain hal seperti antara lain prosedur pelayanan kepada masyarakat, atau hukum acara, atau cara penyelesaian sengketa yang bagaimana yang paling tepat untuk menyelesaikan sengketa di bidang ekonomi; baik yang timbul antara para pengusaha atau antara pengusaha dan aparat pemerintah, atau antara pihak Indonesia dengan pihak asing.

c. Diharapkan bahwa hukum nasional dapat terungkap cara bagaimana lembaga-lembaga hukum, serta. lembaga negara yang lain dapat berperan dalam mengubah wajah aparat negara, pemerintah (birokrasi) dan peradilan yang; cenderung dianggap menjadi ajang KKN dan "pintu masuk" perilaku koruptif, menjadi wajah yang bersih, cantik, dan tepercaya karena memberi pelayanan yang prima kepada masyarakat. Diharapkan juga agar berbagai kekebijaksanaan di bidang ekonomi itu mendapat arahan dan peraturannya di dalam norma hukum, yaitu baik di dalam peraturan perundang-undangan, tetapi juga di dalam yurisprudensi dan hukum kebiasaan; bahkan juga di dalam bidang ilmiah, yaitu Ilmu Hukum Ekonomi, sehingga dengan pendekatan yang sistemik itu diharapkan agar sistem ekonomi nasional kita benar-benar merupakan suatu sistem hukum dalam arti sebenar-benarnya.

d. Diperlukan suatu grand design dan paradigma bersama yang harus melatarbelakangi semua dan setiap aspek kegiatan ekonomi (makro mau pun mikro) dan pengembangan hukum ekonomi sebagai suatu sistem yang utuh, supaya hukum ekonomi dan peraturan hukum di bidang atau yang menyentuh kehidupan ekonomi itu tidak lagi hanya menyediakan atau memenuhi keperluan sesaat seperti pemadam kebakaran, tetapi agar hukum ekonomi benarbenar menyediakan saluran-saluran atau jalur-jalur (channels) melalui mana segala kegiatan ekonomi dapat disalurkan menuju sistem ekonomi nasional yang kita cita-citakan.

\footnotetext{
${ }^{23}$ Adi Sulistiyono, Mengembangkan Paradigma Non-Litigasi di Indonesia, Surakarta.UNS Press, 2005, hlm 27-31.
} 
Karena itu, diupayakan agar setiap topik pembahasan dilakukan para pakar bidang ekonomi atau teknologi maupun pakar hukum yang bersangkutan, terutama mengenai pengembangan berbagai bentuk korporasi di dalam hukum ekonomi Indonesia yang akan datang, yang menurut Kelompok Kerja Bidang Ekuin dilihat sebagai masalah yang masih belum cukup disentuh oleh Hukum Korporasi Indonesia. Walaupun sudah dikenal peraturan yang berasal dari Kitab UndangUndang Hukum Dagang Hindia Belanda rnengenai Firma, C.V., N.V., Cooperatie, dan lain-lain, tetapi sejak Orde Baru hanyalah bentuk N.V., atau P.T., dan bentuk koperasi yang merupakan perhatian para sarjana hukum dan ahli ekonomi. Padahal dewasa ini sudah berkembang berbagai bentuk hibrida baru dan dibutuhkan bentuk-bentuk korporasi yang lebih baru lagi, seperti misalnya "statutory board" yang memungkinkan penggabungan antara swasta dengan pemerintah daerah atau pemerintah pusat, seperti yang dimungkinkan dalam sistem hukum asing.

Yang masih menjadi pertanyaan adalah dimanakah tempat Usaha Dagang, BUMN, khususnya PERUM dan PERSERO serta lain-lain bentuk hibrida seperti Perusahaan Swasta Domestik, atau Perusahaan Penanaman Modal Asing, atau Perusahaan Multinasional, dan sebagainya. Sudah waktunya hukum tentang Pelaku Ekonomi itu diteliti secara integral, baik dalam rangka peranan ekonominya di dalam ekonomi nasional maupun sebagai pranata hukum dalam keseluruhan sistem yang mengatur hak dan kewajiban setiap pelaku hukum itu.

Sampai saat ini belum pernah diatur secara benar hukum kontrak yang harus berlaku bagi kegiatan dan penyusunan kontrak yang berbeda, seperti misalnya untuk berbagai adhesion contracts (contrats d'adhesion), yang di dalam bahasa Indonesia kadang-kadang diterjemahkan sebagai kontrak standar atau kontrak baku, dan yang sifatnya sudah jauh berbeda dengan kontrak sederhana, (simple contracts) yang diatur dalam Kitab Undang-Undang Hukum Perdata Indonesia. Oleh sebab itu, Belanda sendiri sudah hampir 15 tahun yang lalu mengubah asas-asas dan peraturan hukumnya bagi kontrak standar ini, dalam Burgerlijk Wetboeknya yang baru, karena penerapan asas dan peraturan lama (yang sampai sekarang masih diterapkan di Indonesia) diyakini mengakibatkan ketidakadilan bagi pihak yang lemah. Demikian pula hukum kita belum secara jelas mengatur asas-asas dan peraturan yang harus berlaku bagi "government contracts" atau kontrak-kontrak dengan badan-badan atau instansi pemerintah yang sewaktu-waktu dapat mengubah posisi swasta, baik dengan kebijaksanaan pemerintah atau melalui perubahan undangundang. Hal yang sama berlaku bagi kontrak internasional seperti bisa dilihat dalam bab tentang "Algemene Voorwaarden". Apalagi mengenai kontrak-kontrak yang dilangsungkan lewat komputer atau internet (e-contracts) di Indonesia masih terdapat kevakuman hukum, dan adalah sangat tidak benar dan tidak adil, apabila untuk e-contracts dan lain-lain kontrak tersebut di atas dengan gampang dan serta merta digunakan saja peraturan tentang Hukum Kontrak yang berasal dari Code Napoleon, yang lahir pada tahun 1800 untuk diterapkan lebih 2 (dua) abad kemudian. Tidak dapat disangkal bahwa hampir setiap kegiatan ekonomi didasarkan pada kontrak ${ }^{24}$.

Ketika masyarakat mempunyai komitmen untuk melakukan reformasi di bidang politik, ekonomi dan bidang hukum, kesalahan yang dilakukan pada masa lalu, ketika hukum senantiasa ditelantarkan, sebaiknya tidak terulang kembali. Untuk itu, tepat kiranya pada saat kondisi ekonomi Indonesia masih belum pulih seperti sekarang ini kita mulai memberikan skala prioritas utama pada pembangunan hukum ekonomi di Indonesia, agar bisa digunakan sebagai pondasi dan pemandu para pelaku-pelaku ekonomi untuk menjalankan aktivitasnya. Itulah sebabnya,

\footnotetext{
${ }^{24}$ Charles Himawan dan Mochtar Kusumaatmadja, Business Law,Bandung, Padjajaran University Press, $1984 .$, hlm 22.
} 
pemerintah Indonesia tidak hanya harus memusatkan perhatian kepada pemulihan ekonomi, melainkan juga harus meletakkan dasar bagi pertumbuhan ekonomi yang berkelanjutan, lebih efisien dan lebih merata.

\section{PENUTUP}

Dua model hukum ekonomi di Indonesia, yaitu hukum ekonomi pembangunan dan hukum ekonomi sosial. Hukum ekonomi pembangunan merupakan pengaturan mengenai hukum yang meliputi pengaturan dan pemikiran hukum mengenai cara peningkatan dan pengembangan kehidupan perekonomian di Indonesia secara nasional atau menyeluruh, sedangkan dengan hukum ekonomi sosial adalah pengaturan tentang bagaimana hasil pembangunan ekonomi nasional dapat dibagi dengan adil dan merata sesuai nilai-nilai kemanusiaan.

Prinsip hukum sebagai meta norma hukum pada dasarnya memberikan arah tujuan serta penilaian fundamental bagi keberadaan suatu norma hukum. Arah tujuan dan penilaian fundamental Penerapan hukum ekonomi sebagai bagian dari kebijakan atas dasar kepentingan masyarakat dan negara, sehingga kepentingan negara bisa tercapai tanpa harus menyengsarakan masyarakat. Itulah beberapa hukum ekonomi yang terjadi dan terdapat di negara Indonesia, baik secara yang mudah terlihat ataupun dialami, sehingga ke depannya diharapkan bisa berjalan dengan baik dan berfungsi dengan baik demi kesejahteraan seluruh masyarakat Indonesia.

Hukum ekonomi merupakan bagian dari sistem hukum yang ada di Indonesia serta berperan sangat besar dalam pengaturan kegiatan perekonomian di Indonesia sebagai sesuatu yang sifatnya sangat fundamental, maka pengaturan mengenai hukum ekonomi sesungguhnya dapat kita temui dengan mudah berbagai peraturan perundang-undangan di Indonesia. Jelas bahwa tidak hanya bidang ekonomi yang harus ditangani secara konseptual, sistemik dan profesional.

\section{DAFTAR PUSTAKA}

Amanda J. Perry, "The Relationship between legal Systems and Economic Development : Integrating

Economic and Cultural Approaches", Journal of Law and Society, vol. 29, no.2, June 2002.

Ai Siti Farida, Sistem Ekonomi Indonesia, Jakarta, Pustaka Setia, 2011

Adi Sulistiyono, Reformasi Hukum Ekonomi dalam Era GlobalisasiEkonomi,Surakarta.UNS Press, 2005, Mengembangkan Paradigma Non-Litigasi di Indonesia, Surakarta.UNS Press, 2005.

Christianto Wibisono, Menelusuri Akar Krisis Indonesia, Jakarta.PT. Gramedia Pustaka Utama, 1998, T Mulya Lubis, Hukum dan Ekonomi : Beberapa Pilihan Masalah, Jakarta. Pustaka Sinar Harapan, 1991

Gunarto Suhardi, Peranan Hukum Dalam Pembangunan Ekonomi, Yogyakarta. Universitas Atma Jaya, 2002,

Hikmahanto Juwana, Bunga Rampai Hukum Ekonomi danHukum Internasional, Jakarta.Lentera Hati, 2002,

Charles Himawan dan Mochtar Kusumaatmadja, Business Law,Bandung.Padjajaran University Press, 1984,

Peter Mahmud Marzuki, Pengantar Ilmu Hukum, Jakarta, Kencana, 2016.

G.W Paton, Textbook of of Jurisprudence, English language book Society, Oxford University Press, London, 1972. Di kutip dari Peter Mahmud Marzuki I, Ibid..

Sumantoro, Hukum Ekonomi, Jakarta.UI Press, 2008 
Jimly Asshiddiqie, Konstitusi \& Konstitusionalisme Indonesia, Jakarta, Edisi Revisi, Konstitusi Press, 2005.

Theo Huijbers, Filsafat Hukum Dalam Lintas Sejarah, Yogyakarta, Kanisius, 1990.

M. Noor Syam, Penjabaran Filsafat Pancasila Dalam Filsafat Hukum, Malang, Lab Pancasila Ikip, Jeremy Bentham, An Introduction to the Principles Of Morals and Legislation, Kitchener, Batoche Books, 2000.

Shindarta, Utilitarianisme, Jakarta, Penerbit UPT Universitas Tarumanegara, 2007.

M.D.A. Freeman, Lloyds Introduction to Jurisprudence, London, Steven And Sons, 2001. 